\title{
Effects of Short-duration and Continuous Grazing on Bob- white and Wild Turkey Nesting
}

\author{
LAURA J. BAREISS, PAUL SCHULZ, AND FRED S. GUTHERY
}

\begin{abstract}
We compared effects of short-duration and continuous grazing on nesting cover and success of bobwhites and wild turkeys in south Texas during 1984. Coverage, density, and dispersion of suitable nest sites and loss rates of artificial nests were not affected by grazing treatment.
\end{abstract}

The effects of cell-type, short-duration grazing (SDG) on ground-nesting gamebirds are largely undetermined. Concern that the system may impact these birds has arisen because a single herd of livestock is concentrated in small pastures for short periods. Stocking densities in paddocks may be 5 to 10 times higher with SDG than with continuous grazing (CG). Likewise, the overall stocking rate may be increased under SDG.

Livestock concentrations associated with SDG could increase trampling of ground nests and reduce nesting cover. Bryant et al. (1982) modeled loss rates and concluded that the relative probability of trampling was similar under SDG and CG. Koerth et al. (1983) found that the trampling of clay pigeon targets, placed to simulate ground nests, was similar under the 2 grazing programs.

We compared the effects of SDG and CG on loss rates of ground nests and examined their impact on availability of nesting cover for bobwhites (Colinus virginianus) and wild turkeys (Meleagris gallopavo).

\section{Study Area and Methods}

The study was conducted during 1984 on the Encino Division of the King Ranch, Brooks County, and on the Welder Wildlife Foundation Refuge, San Patricio County, Texas. Soils at the Encino area were deep, level to undulating sands of the SaritaNueces-Falfurrias Association. Honey mesquite (Prosopis glandulosa) dominated the woody vegetation, which included occasional mottes of live oak (Quercus virginiana). Dominant grasses included threeawns (Aristida spp.) while crotons (Croton spp.), sunflowers (Helianthus spp.), and camphorweed (Heterotheca sp.) dominated the forbs. The 8-paddock, 1,142-ha SDG cell, established in 1983, was stocked at $4.5 \mathrm{ha} / \mathrm{AU}$ with the herd rotated every 4-9 days. The CG pasture (1,242 ha) was stocked at $7.3 \mathrm{ha} / \mathrm{AU}$.

Soils on th Welder area were primarily level Victoria clays that supported mixed brush, mainly mesquite (Drawe et al. 1978). Dominant grasses were Texas wintergrass (Stipa leucotricha) and meadow dropseed (Sporobolus asper). Prairie coneflower (Ratibida columnaris), western ragweed (Ambrosia psilostachya), and Ruellia sp. were dominant forbs. The 10-paddock, 219-ha SDG cell, established in 1982, was stocked at 2.8 ha/ AU with the herd rotated every 3-6 days. The CG pasture ( $253 \mathrm{ha}$ ) also was stocked at $2.8 \mathrm{ha} / \mathrm{AU}$.

We estimated availability of nesting cover (clumps of residual grasses) during March 1984 with 50, 30-m line transects/grazing treatment per study area. Lines were established at right angles to bobwhite counting transects with random starting points and subsequent measurements at $30-\mathrm{m}$ intervals. Clumps of residual grasses were considered suitable for bobwhite nesting if they

\footnotetext{
At the time of research, authors were Welder Wildlife Fellow, Department of Range and Wildlife Management, Texas Tech University, Lubbock, Texas 79409; research assistant, and associate research scientist, Caesar Kleberg Wildlife Research Institute, Texas A\&I University, Kingsville 78363. Bareiss is currently research associate. Caesar Kleberg Wildlife Research Institute. Support for this study was provided by the Rob and Bessie Welder Foundation (Contribution No. 281) and the Caesar Kleberg Foundation for Wildlife Conservation.

Manuscript accepted 9 July 1985.
}

exceeded $20 \mathrm{~cm}$ height and $30 \mathrm{~cm}$ diameter (Lehmann 1976) and suitable for turkey nesting if at least $45 \mathrm{~cm}$ height (Cook 1972) and $60 \mathrm{~cm}$ diameter (D. Ransom, Welder Wildlife Fellow, pers. comm.). Percentage of suitable nesting cover intercepted by each line, number of clumps/line, and frequency of lines with one or more clumps were calculated to evaluate effects of grazing treatments on coverage, density, and dispersion of nesting cover.

We used artificial bobwhite and turkey nests to determine the effects of SDG and CG on loss rates of ground nests during April-June on the Encino Division and May-July on the Welder Refuge. Cattle completed 1.2 rotations in the Welder SDG cell and 0.88 rotations in the Encino SDG cell during the study. Transects with random starting points were used to systematically place 50 turkey "nests" and 100 bobwhite "nests" at least 50-m apart and at sites of suitable cover (Lehmann 1976, Cook 1972) under each grazing treatment and study area ( $N=600$ nests). No attempt was made to construct a nest bowl. Turkey nests contained 10 domestic turkey eggs and quail nests contained 8 bobwhite eggs. Nest locations were marked with flagging on a nearby shrub or stake. Nests were checked weekly for 6 weeks, which corresponded with the normal laying and incubation period (Bailey and Rinell 1967). Cause of loss was determined by sign at the nest site (Baker 1979). Eggs in undisturbed nests were replaced after 2 weeks so that rotting would not affect results.

The experimental design for analysis of nesting cover data was a $2 \times 2$ factorial ( 2 study areas, 2 grazing treatments). Numerical ranks were assigned to dependent variables because of nonnormality. Analysis was applied to the ranks, resulting in nonparametric tests (Conover and Iman 1981). Variance among subsamples within each pasture was used as the error term. Consequently, statistical inference is limited to these specific pastures and does not extend to the vegetation types they represent.

\section{Results and Discussion}

Coverage and density of nesting cover for bobwhites and wild turkeys were higher $(P<0.002)$ on the Welder area than on the Encino area (Table 1). Likewise, nesting cover for both species was more broadly distributed on the Welder area. This occurred in spite of the fact that the stocking rate was 2 to 3 times higher on the Welder area than on the Encino area. The Welder area has a history of light grazing pressure and receives an average annual precipitation $15 \mathrm{~cm}$ greater than the Encino area.

Grazing treatment had no effect $(P>0.2)$ on coverage, density, or dispersion of nesting cover for either bird (Table 1). These variables appeared higher for turkeys under SDG than CG on the Encino area because sampling lines intersected stands of gulf cordgrass (Spartina spartinae) on the SDG treatment, whereas none was intersected on the CG treatment. Both areas had low, thorny brush which protected residual cover from grazing (Stoddard 1931, Moore 1972), thus neutralizing the effects of different stocking intensities.

Effects of the grazing treatments on coverage and density of bobwhite nesting cover depended on study location (interaction $P<0.03$ ). This occurred because nesting coverage and density were higher on the Welder area than the Encino area in the SDG treatment. A possible explanation for this was that the SDG treatment was stocked nearly 2 times higher than the CG treatment on the Encino area, whereas the grazing treatments on the Welder area were stncked at the came rate 
Table 1. Availability of nesting coverts for bobwhites and wild turkeys in rangeland under continuous grazing (CG) and short-duration grazing (SDG) on 2 study areas in south Texas, March 1984.

\begin{tabular}{|c|c|c|c|c|c|c|c|c|c|c|c|}
\hline \multirow[b]{3}{*}{ Species } & \multirow[b]{3}{*}{ Area } & \multicolumn{4}{|c|}{ Percent coverage } & \multicolumn{4}{|c|}{ Coverts $/ 30 \mathrm{~m}$} & \multirow{2}{*}{\multicolumn{2}{|c|}{$\begin{array}{c}\text { Frequency } \\
(\%)\end{array}$}} \\
\hline & & \multicolumn{2}{|c|}{$\mathrm{CG}$} & \multicolumn{2}{|c|}{ SDG } & \multicolumn{2}{|c|}{ CG } & \multicolumn{2}{|c|}{ SDG } & & \\
\hline & & $\bar{X}$ & SE & $\overline{\boldsymbol{X}}$ & SE & $\overline{\boldsymbol{X}}$ & SE & $\overline{\boldsymbol{X}}$ & $\mathrm{SE}$ & CG & $\widehat{S D G}$ \\
\hline \multirow[t]{2}{*}{ Bobwhite } & Welder & 7.2 & 0.7 & 8.0 & 0.7 & 3.9 & 0.3 & 5.2 & 0.3 & 92 & 96 \\
\hline & Encino & 3.3 & 0.7 & 2.6 & 0.7 & 2.0 & 0.3 & 1.5 & 0.3 & 74 & 66 \\
\hline \multirow[t]{2}{*}{ Turkey } & Welder & 0.9 & 0.4 & 0.9 & 0.4 & 0.2 & 0.1 & 0.3 & 0.1 & 24 & 26 \\
\hline & Encino & 0.1 & 0.4 & 0.3 & 0.4 & 0.1 & 0.1 & 0.3 & 0.1 & 4 & 12 \\
\hline
\end{tabular}

${ }^{2}$ Frequency of $30-\mathrm{m}$ lines $(N=50$ ) with one or more nesting coverts.

Losses of artificial nests were not affected by study area or grazing treatment. Total losses exceeded $84 \%$ for a given area and treatment (Table 2). More than $90 \%$ of the losses were attributed to predation by mammals, snakes, or unknown agents. One wild turkey nest was trampled in the SDG treatment at the Welder area.

Table 2. Percentage losses of artificial bobwhite ( $N=100 /$ treatment/area) and wild turkey nests $(N=50 /$ treatment/area) in rangeland under continuous graxing (CG) and short-duration grazing (SDG) on 2 study areas in south Texas, April-July 1984.

\begin{tabular}{lccccc}
\hline \hline & \multicolumn{3}{c}{ Bobwhite } & & \multicolumn{2}{c}{ Wild turkey } \\
\cline { 2 - 3 } \cline { 6 - 6 } Area & CG & SDG & & CG & SDG \\
\hline Welder & 84 & 96 & & 92 & 100 \\
Encino & 96 & 94 & & 92 & 88 \\
Average & $\overline{90}$ & $\overline{95}$ & & $\overline{92}$ & $\overline{94}$ \\
\hline
\end{tabular}

In south Texas, Baker (1979) found that loss of artificial turkey nests to predation exceeded $90 \%$ in a 6-week study. He determined survival of simulated nests was higher in pastures under 4-pasture deferred rotation and high-intensity low-frequency grazing than CG.

The present data add to evidence (Bryant et al. 1982, Koerth et al. 1983) that SDG is not associated with increased trampling losses of ground nests in comparison with CG. This finding, however, must be tempered by conditions obtaining in this and other studies. Obviously, at extremely high stocking rates, heavy losses to trampling are possible. We saw no trampling losses at a maximum paddock density of $0.6 \mathrm{ha} / \mathrm{AU}$ on the Encino area. At a maximum of $0.4 \mathrm{ha} / \mathrm{AU}$, one nest was trampled on the Welder area. This latter value might serve as a research and management hypothesis, i.e., trampling losses may not be a management concern unless paddock density exceeds 0.4 ha/ $\mathrm{AU}$.

\section{Literature Cited}

Bailey, R.W., and K.T. Rinell. 1967. Events in the turkey year, p. 73-92. In: O.H. Hewitt (ed). The Wild Turkey and Its Management. The Wildlife Society, Washington, D.C.

Baker, B.W. 1979. Habitat use, productivity, and nest predation of Rio Grande turkeys. Ph.D. Diss. Texas A\&M Univ., College Station.

Bryant, F.C., F.S. Guthery, and W.M. Webb. 1982. Grazing management in Texas and its impact on selected wildlife, p.94-112. In.J.M. Peek, and P.D. Dalke (eds.). Symp. Wildlife-Livestock Relationships. Univ. of Idaho, Moscow.

Conover, W.J., and R.L. Iman. 1981. Rank transformations as a bridge between parametric and nonparametric statistics. Amer. Statistician 35:124-129.

Cook, R.L. 1972. A study of nesting turkeys in the Edwards Plateau of Texas. Proc. Ann. Conf. S.E. Ass. Game and Fish Commissioners 26:236-244.

Drawe, D.L., A.D. Chamrad, and T.W. Box. 1978. Plant communities of the Welder Wildlife Refuge. Welder Wildl. Found. No. 5, Ser. B (Rev.).

Koerth, B.H., W.M. Webb, F.C. Bryant, and F.S. Guthery. 1983. Cattle trampling of simulated ground nests under short duration and continuous grazing. J. Range Manage. 36:385-386.

Lehmann, V.W. 1976. Bob-whites (sic) of the brush country. Amer. Field (December):766-769.

Moore, W.H. 1972. Managing bobwhites in the cutover pinelands of south Florida, p. 56-65. In: J.A. Morrison and J.C. Lewis (eds). First National Bobwhite Quail Symposium.

Stoddard, H.L. 1931. The bobwhite quail-its habits, preservation, and increase. Charles Scribner's Sons, New York, N.Y.

\title{
Vegetation Changes on Western Rangelands
}

\author{
by Farrel A. Branson
}

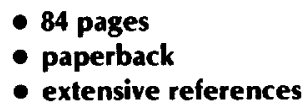

\author{
- illustrated \\ - $\$ 4.00$ postpaid
}

This book provides a comprehensive source of information on vegetation changes that have occurred on western rangelands during the past 100 years. It is illustrated with maps and photographs. The comments of one reviewer of the manuscript are as follows:

"It is a very good source of information on vegetation types for students as well as range professionals. It would be a good text for range community courses and portions could be used for selected assignments in other range courses. It brings together the primary references and provides so much more information to date than our present texts. I strongly believe that it will be a well-referred source. It would also improve the image of the range profession as one that is tremendously knowledgeable about the resources it manages. Branson's style of writing is good. It is straight forward and uncomplicated."-Dr. M. Hironaka, University of Idaho, Moscow, Idaho.

Range professors and students, private and public range managers, soil conservationists, wildlife managers, and others will find the book a valuable contribution to their libraries. Available from the Society for Range Management 2760 W. Fifth Ave., Denver, CO 80204 . 